\section{Neuroscientist resigns over recruiting battle}

A bruising clash between neuroscientists at the Massachusetts Institute of Technology (MIT) ended last week when Nobel prizewinner Susumu Tonegawa quit as head of the Picower Institute for Learning and Memory in Cambridge.

Tonegawa was accused this summer of discouraging a new female recruit from accepting a position at the neighbouring McGovern Institute for Brain Research, also part of MIT, reportedly because her work would compete with that of his lab. An investigation into the incident earlier this month concluded that Tonegawa acted inappropriately, but its report provoked anger from Tonegawa's critics, who felt that he had escaped too lightly.

His departure may soothe relations between the two institutes. The university said that it was Tonegawa's decision to step down, and that he will remain an MIT professor.

\section{Terror law tightens on animal-rights protesters}

The United States looks set to expand the reach of a 1992 law aimed at protecting animal facilities from violent activists. On 13 November, the House of Representatives passed the Animal Enterprise Terrorism Act; the Senate has already approved it, and President George W. Bush is expected to sign it into law.

The bill makes it a federal crime to use force, violence or threats against companies affiliated to animal enterprises, such as accountants and insurers, and their employees. The 1992 law explicitly covered only animal facilities themselves, from research labs to circuses and zoos. Animal activists have recently begun targeting employees of affiliated companies. The

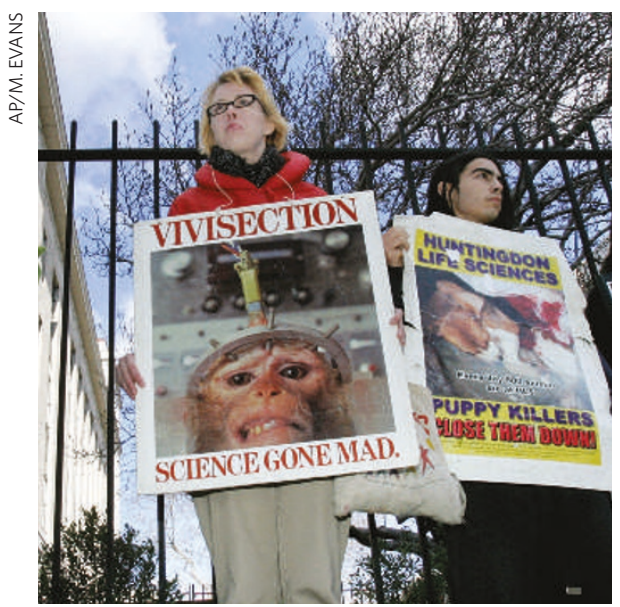

Under the latest bill covering the actions of animalrights protesters, peaceful picketing remains legal.

\title{
Submarine eruption bares volcanic island in Tonga
}

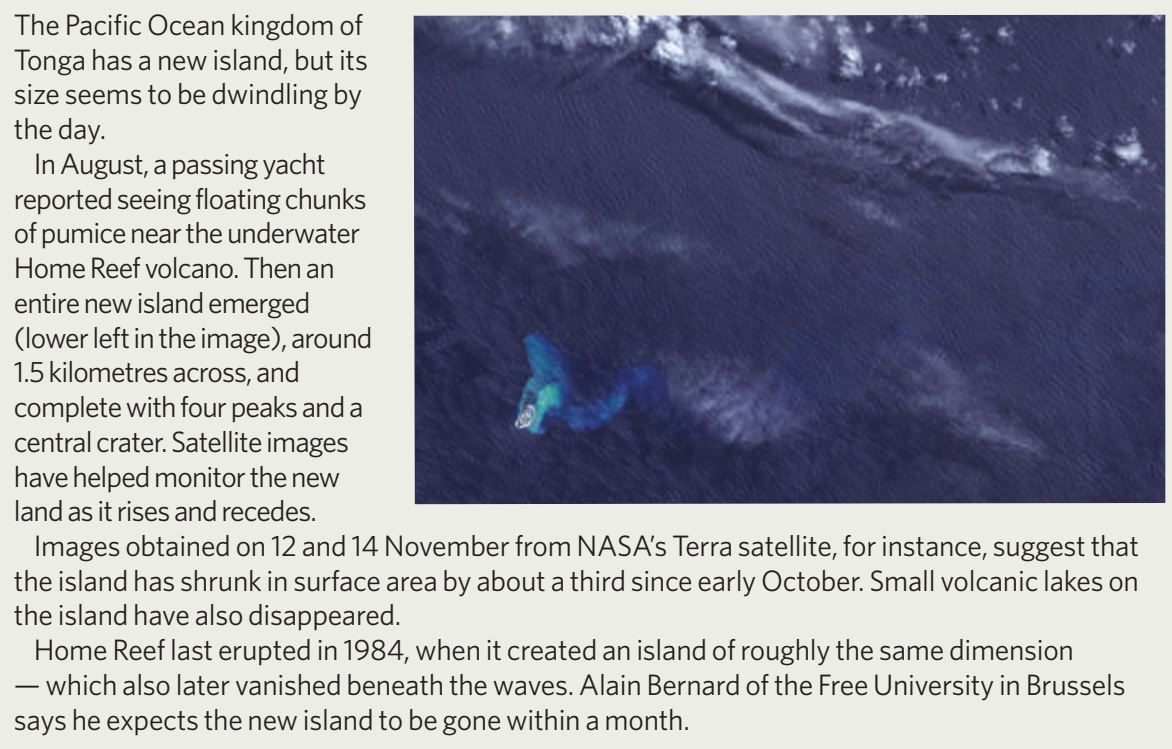

bill also adds a new criminal offence: intentionally placing a person or their family in reasonable fear of death or serious bodily injury.

The bill does not define as crimes activities such as peaceful picketing and economic boycotts. Some civil-liberties advocates have protested against the legislation.

\section{Gene-sequencing patent challenged after 25 years}

Ownership of a central invention underlying gene sequencing was called into question this month when the US Patent and Trademark Office allowed a small company to challenge the patent almost 25 years after it was filed.

The patent, covering basic DNA gelsequencing technology, is owned by the California Institute of Technology (Caltech) in Pasadena and licensed exclusively to Applied Biosystems of Foster City, California. But Enzo Biochem, based in Farmingdale, New York, claims to have filed its patent application in 1982, months before Caltech scientists filed theirs. It says that continued amendments and rejections delayed the progress of its application, which has become public only now.

The patent office is expected to take up to two years to reach a decision.

\section{US Senate approves deal to aid India's nuclear plans}

A controversial Indo-US nuclear deal overcame a final hurdle last week when it gained the approval of the US Senate.

India's leading nuclear scientists, some of whom had opposed the deal (see Nature 442,$859 ; 2006$ ), say celebrations should wait until it is clear that the final legislation expected to be signed by President George W. Bush next month - addresses their concerns. They say the bill, first mooted 16 months ago, still contains clauses that prevent India from stockpiling reactor fuel, conducting nuclear tests and reprocessing spent fuel.

India's prime minister, Manmohan Singh, says Bush has assured him that "the final outcome will be in line with Indian concerns". The deal is intended to provide India with access to nuclear technology and cheap fuel in exchange for making its nuclear programme transparent.

\section{Supernovae expose dark matter's 9-billion-year past}

Dark energy - the force thought to be causing the Universe to expand at an ever-accelerating rate - has been around for at least 9 billion years, a study shows. And the mysterious force seems to have been much the same then as it is today.

A team led by Adam Riess of Johns Hopkins University in Baltimore, Maryland, has used the Hubble Space Telescope to observe 24 old and distant exploded stars, or supernovae. Similar work on younger supernovae had revealed that the stars are farther away than would be expected if the Universe was expanding without the presence of dark energy.

The strength of the dark energy seems to have been much the same 9 billion years ago, says Riess, although the error bars on the team's results are very large. The findings will be published in The Astrophysical Journal. 